\title{
15-49 Yaş Evli Kadınların Aile Planlamasına İlişkin Tutumlarının Belirlenmesi
}

\section{Determination of Attitudes of 15-49 Age Married Women towards Family Planning}

\author{
Feyza Nazik ${ }^{1}$ (D) Şule Mumcu ${ }^{1}$ (D) Mehtap Sönmez² ${ }^{\text {(D) }}$ Ayşe Nur Yılmaz ${ }^{3}$ (D) Özlem Doğan Yüksekol ${ }^{3}$ \\ ${ }^{1}$ Bingöl Üniversitesi Sağlık Bilimleri Fakültesi, Hemşirelik Bölümü, Bingöl, TÜRKiYE \\ ${ }^{2}$ Kahramanmaraş Sütçü İmam Üniversitesi Sağlık Bilimleri Fakültesi, Hemşirelik Bölümü, Kahramanmaraş, TÜRKiYE \\ ${ }^{3}$ Fırat Üniversitesi Sağlık Bilimleri Fakültesi, Ebelik Bölümü, Elâzı̆̆g, TÜRKiYE
}

Geliş tarihi/ Date of receipt: 16/02/2021 Kabul tarihi/ Date of acceptance: 15/07/2021

(C) Ordu University Faculty of Health Sciences, Department of Nursing, Turkey, Published online: 26/12/2021

\section{Öz}

Amaç: Bu araştırma, 15-49 yaş evli kadınların aile planlamasına ilişkin tutumlarını belirlemek amacıyla yapıldı.

Yöntem: Kesitsel-tanımlayıcı tipte olan araştırmanın örneklemini, Nisan-Haziran 2019 tarihleri arasında, Türkiye'nin doğusunda bulunan bir ilde çalışmaya katılmayı kabul eden 323 kadın oluşturdu. Veriler, "Kişisel Bilgi Formu” ve "Aile Planlaması Tutum Ölçeği (APTÖ)” ile toplandı. Verilerin analizinde tanımlayıcı istatistikler, bağımsız gruplarda $t$ testi ve tek yönlü varyans analizi kullanıldı.

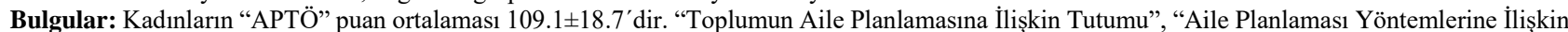

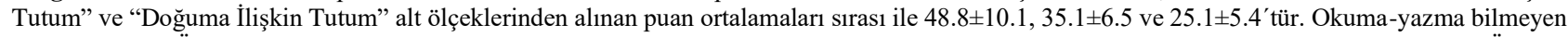
kadınların APTÖ puan ortalamaları 100.2 \pm 19.0 , üniversite mezunlarının 125.2 \pm 18.4 'tür (p<0.05). Çekirdek ailede yaşayan kadınların APTÖ puan ortalaması 110.6 \pm 18.8 , geleneksel ailede yaşayan kadınların APTÖ ortalaması $101.8 \pm 16.8$ 'dir (p<0.05). Hiç doğum yapmayan, aile planlaması konusunda danışmanlık alan ve modern yöntem kullanan kadınların APTÖ puan ortalaması, 3 ve üzerinde doğum yapmış, aile planlaması danışmanlığ almamış ve geleneksel yöntem kullanan kadınların APTÖ puan ortalamasından yüksektir $(\mathrm{p}<0.05)$. İstenmeyen gebelik ve isteyerek düşük yapma ile APTÖ puan ortalaması arasında istatistiksel olarak anlamlı farklılık saptanmamıştır ( $>0.05)$.

Sonuç: Araștırmanın sonucunda, kadınların aile planlaması yöntem kullanmaya yönelik tutumlarının olumlu ancak yeterli düzeyde olmadığı, eğitim düzeyi yüksek, çekirdek ailede yaşayan, çalışan ve daha önce aile planlaması danışmanlık hizmeti alan kadınların APTÖ puan ortalamalarının daha yüksek olduğu saptandı. Bu sonuçlar doğrultusunda, toplumda aile planlamasına olumlu tutum geliştirilmesi için verilecek eğitimlerde; eğitim düzeyi düşük olan, geniş aile yapısına sahip olan, çocuk sayısı fazla olan ve aile planlaması konusunda bilgi almayan kadınlara öncelik verilmesi önerilebilir. Anahtar Kelimeler: Tutum, aile planlaması, kadın

\section{ABSTRACT}

Objective: This research was conducted to determine the attitudes of married women aged 15-49 towards family planning.

Methods: The sample of the research is cross-sectional, between April-June 2019 to participate in a province in the east of Turkey has created 323 women who accepted. The data were collected using "Personal Information Form" and "Family Planning Attitude Scale. Descriptive statistics, independent groups t-test and one-way analysis of variance were used in data analysis.

Results: Women's FPAS mean score is $109.1 \pm 18.7$. The mean scores obtained from the subscales of society's attitude towards family planning, attitude towards family planning methods and attitude towards birth were $48.8 \pm 10.1,35.1 \pm 6.5$ and $25.1 \pm 5.4$, respectively. FPAS mean score of illiterate women is $100.2 \pm 19.0$, university graduates are $125.2 \pm 18.4(\mathrm{p}<0.05)$. The mean APTÖ score of women living in a nuclear family is $110.6 \pm 18.8$, and the mean of women living in a traditional family is $101.8 \pm 16.8$. Women who never gave birth, received consultancy about family planning and used modern methods, mean FPAS score average of women who gave birth to 3 or more, did not receive family planning counseling, and used traditional methods ( $\mathrm{p}<0.05)$. There is no significance between unintended pregnancy and induced miscarriage and FPAS score ( $\mathrm{p}>0.05)$.

Conclusion: As a result of the study, it was determined that women's attitudes towards using family planning methods were not at a positive but sufficient level, women with a high level of education, living in the nuclear family, working and previously receiving family planning counseling service had higher mean FPAS scores. In line with these results, in the trainings to be given to develop a positive attitude towards family planning in society; It may be suggested to give priority to women with a low level of education, an extended family structure, a high number of children and no information on family planning.

Keywords: Attitude, family planning, woman

ORCID IDs of the authors: NF: 0000-0003-3865-6868; MŞ: 0000-0002-1730-2721; SM: 0000-0001-6975-0262; YNA: 0000-0003-0489-7639; YDÖ: 0000-0002-1761-1479

Sorumlu yazar/Corresponding author: Dr. Öğr. Üyesi Ayşe Nur Yılmaz

Fırat Üniversitesi Sağlık Bilimleri Fakültesi, Ebelik Bölümü, Elâzı̆̆, TÜRKIYE

e-posta/e-mail: anucar@ firat.edu.tr

* Bu çalışma, 4. Uluslararası 22. Ulusal Halk Sağlığı Kongresi'nde sözel bildiri olarak sunulmuştur (13-19 Aralık 2020).

Atıf/Citation: Nazik F, Mumcu Ş, Sönmez M, Yılmaz AN, Doğan Yüksekol Ö. (2021). 15-49 Yaş evli kadınların aile planlamasına ilişkin tutumlarının belirlenmesi. Ordu Üniversitesi Hemşirelik Çalışmaları Dergisi, 4(3), 326-336. DOI: 10.38108/ouhcd.881578 


\section{Giriş}

Kadın sağlığı üzerinde etkili olan en önemli faktörlerden biri doğurganlık özellikleridir. Yüksek doğurganlık oranları, riskli gebelik ve doğumlara yol açarak, anne-bebek sağlığına yönelik olumsuz sonuçlar oluşturabilecek riskleri artırmaktadır (Gözükara ve ark., 2015). Ülkemizde planlanmamış gebeliklerin fazlalığı, nüfus artıș hızının ve annebebek ölüm oranlarının yüksekliği nedeniyle aile planlaması temel sağlık hizmetleri içinde sunulmaktadır (Egelioğlu Cetişli ve ark.,2020; Kul Uçtu ve ark., 2017). Aile planlaması, istenmeyen gebeliklerin ve aşırı doğurganlığın önüne geçerek anne-çocuk sağlığının korunmasını ve geliştirilmesini amaçlar. Ayrıca toplumun sağlık düzeyinin iyileştirilmesi ve yükseltilmesinde önemli rolü vardır (Ejder Apay ve ark., 2010; Gavas ve İnal 2019; Tezel ve ark., 2015). Aile planlamas1 hizmetlerinin anne ve çocuk sağllğı üzerine olumları katkıları bilinmesine rağmen, ülkemizde aile planlaması yöntemi kullanma oranları hala istenen düzeyde değildir (Öztaş ve ark., 2015).

Türkiye Nüfus ve Sağlık Araştırması (TNSA) 2018 verilerine göre, halen evli kadınların \%30'u herhangi bir aile planlaması yöntemi kullanmamaktadır. Bu oran son beș y1lda \%4 artış göstermiştir. Bunun nedeni geri çekme ve rahim içi araç gibi yöntemlerin kullanımının azalmasıdır. Modern aile planlaması yöntemlerini kullananların oranı \%49 iken geleneksel aile planlamas yöntemlerini kullananların oranı \%21'dir. Bölgeler aras1 farklılıklara bakıldığında; modern yöntem kullanma oranlarının en düşük olduğu bölgenin Ortadoğu Anadolu bölgesi olduğu görülmektedir. Bu bölgede modern yöntem kullanım oran1 $\% 40.2$ iken geleneksel yöntem kullanım oran1 \%26, yöntem kullanmayanların oranı ise \%33.8'dir. Gebeliği önleyici yöntem kullanma oranlarının düşük olması nedeniyle istenmeyen gebelik ve istemli yapılan düşüklerin oranı her geçen gün artmaktadır. Türkiye'nin Doğu bölgesinde istenen doğurganlık hızı 2.6 iken toplam doğurganlık hızı 3.2'dir (TNSA, 2018). Kadının ruhsal ve fiziksel açıdan kendisini gebeliğe hazır hissedeceği zamana kadar istenmeyen bir gebelikten etkili bir şekilde korunması, kendisinin ve bebeğinin sağlığı için önem taşımaktadır (Egelioğlu Cetişli ve ark., 2020). Çünkü istenmeyen gebelikler ve buna bağlı olarak isteyerek yapılan düşükler önemli bir halk sağlı̆ 1 sorunudur ve doğurganlık dönemindeki kadınların başlıca ölüm nedenleri arasında yer almaktadır (Şenoğlu ve ark., 2019).
Aile planlaması, sadece çocuk sayısının kısitlanmas1 ve nüfusun azaltılması olarak değerlendirilmemelidir. Uygun doğum aralığının ve doğum zamanının belirlenmesi hem anne-bebek sağlı̆̆ını, hem de toplum sağlı̆̆ını olumlu etkileyecektir (Bostanc1, 2011). Aile planlaması yöntem kullanımını etkileyen pek çok faktör vardır (Gözükara ve ark., 2015). Türk toplumunda genellikle doğurganlığın kadının statüsünü artırdığına inanılmakta ve bu nedenle kadınlar aile planlaması yöntemlerini kullanmak istememektedir (Arslan ve ark., 2019). Literatür incelendiğinde, etkin aile planlaması yöntemi kullanmayı etkileyen faktörler arasında kadının ve çevresinde yaşayan bireylerin aile planlaması yöntemlerine ilişkin tutumlarının olduğu görülmektedir (Ayaz ve Yaman Efe, 2009; Ejder Apay ve ark., 2010; Gözükara ve ark., 2015; Örsal ve Kubilay, 2007; Tezel ve ark., 2015). Tutumların doğrudan olmasa da davranışları etkilediği bilinmektedir. Bireyin kendisinin ve çevresindeki kişilerin aile planlamasına yönelik tutumları, istenilen aile planlaması davranışını sağlamada önemli rol oynayabilmektedir (Tezel ve ark., 2015). Yapılan bir çalışmada, kadının öğrenim düzeyi, gelecekte çocuk isteme, gebelik sayısı, herhangi bir aile planlaması yöntemi duyma ve/veya kullanma gibi özelliklerin aile planlamasına yönelik tutumları etkilediği belirtilmektedir (Ayaz ve Yaman Efe, 2009). Bireylerin aile planlaması yöntemlerine yönelik tutumlarının belirlenmesi için öncelikle aile planlaması yöntemleri konusundaki düşünce, bilgi, inanç ve tutum farklılıklarının belirlenmesi gerekmektedir (Gözükara ve ark., 2015). Kadınların aile planlamasına yönelik olumlu tutumlarını davranışa dönüştürmek için, eğitim programlarının ve danışmanlık hizmetlerinin yaşanılan toplumun sosyo-ekonomik ve kültürel durumu göz önünde bulundurularak planlanması ve uygulanması gerekmektedir (Öngen ve Kurca, 2020). Aile planlamas1 hizmetlerini yürüten en önemli sağl1k profesyonelleri ebeler ve hemşirelerdir. Kadınların, aile planlamasına ve doğurganlığa ilişkin tutumlarının, kullandıkları kontraseptif yöntemlerinin belirlenmesi planlanacak ebelik ve hemşirelik girişimlerine rehberlik edebilecektir. $\mathrm{Bu}$ araştırma, evli kadınların aile planlamasına ilişkin tutumlarını belirlemek amaciyla yap1ld.

\section{Araştırma Soruları}

- 15-49 yaş evli kadınların sosyo-demografik özellikleri aile planlamasına yönelik tutumlarını etkiler mi? 
- 15-49 yaş evli kadınların bazı obstetrik özellikleri aile planlamasına yönelik tutumlarını etkiler mi?

\section{Yöntem}

\section{Araştırmanın Türü}

Araştırma kesitsel-tanımlayıcı tiptedir.

\section{Araştırmanın Yeri}

Araştırma Türkiye'nin doğusunda bulunan bir il merkezinde 15 Nisan-15 Haziran 2019 tarihleri arasinda yapild 1 .

\section{Araştırmanın Evreni ve Örneklemi}

Araştırmanın evrenini il merkezinde yaşayan 1549 yaș kadınlar oluşturdu. İl merkezinden rastgele seçilen üç Aile Sağlığı Merkezine kayıtlı olan evli kadınlara ev ziyaretleri ile anket formu uygulandi. 15-49 yaş kadınlara ulaşmada rastgele örneklem yöntemi kullanıldı. Örneklemi belirlemek için, \%95 güven aralığında, aile planlaması kullanma sıklığı $\% 70$ (TNSA, 2018) alınarak evrendeki birey sayıs1 bilinmeyen örneklem yöntemi kullanıldı. Araştırma 15-49 yaş aralığında evli olan 323 kadın ile tamamlandi.

\section{Araștırmaya dahil edilme kriterleri;}

Araştırmaya katılmaya gönüllü olma,

Evli olma,

Psikiyatrik bir hastalığın olmaması

15-49 yaş grubunda olma olarak

İletişim probleminin olmaması olarak belirlendi.

Araştırmaya dahil edilmeme kriterleri;

Araştırmaya katılmaya gönüllü olmama,

Bekar olma,

Psikiyatrik bir hastalık varlığ1,

15 yaş ve altında ve 50 yaş ve üzerinde olma

İletişimi engelleyecek bir problem varlığı olarak belirlendi.

\section{Veri Toplama Form ve Araçları \\ Kisisel Bilgi Formu}

Araştırmacılar tarafindan literatür taranarak hazırlanan bu form, araştırmaya dahil edilen evli kadınların sosyodemografik (yaş, çalışma durumu, aile tipi, eğitim vb.) ve obstetrik özellikleri (ilk gebelik yaşı, yaşayan çocuk sayısı, spontan düşük, isteyerek düşük vb.) içeren 20 sorudan oluşmaktadır (Çakmak ve ark., 2015; Egelioğlu Cetişli ve ark., 2020; Ejder Apay ve ark., 2010; Tezel ve ark., 2015)

\section{Aile Planlaması Tutum Ölçeği}

Aile Planlaması Tutum Ölçeği (APTÖ), Örsal ve Kubilay tarafından 2007 yılında geliştirilmiştir. Ölçek, 34 maddeden oluşmakta ve 5'li likert tiptedir. Ölçekteki her bir ifadenin l'den 5'e kadar bir puanı vardır. Ölçekten toplamda 37-170 puan alınmaktadır.
Ölçekten alınan puanlar arttıkça aile planlaması tutumu da pozitif yönde artmaktadır. Ölçek "Toplumun Aile Planlamasına İlişkin Tutumu" (1.-15. maddeler), "Aile Planlaması Yöntemlerine İlişkin Tutum” (16.-26. maddeler) ve "Doğuma İlişskin Tutum" (27.-34. maddeler) olmak üzere üç alt boyuta sahiptir. Örsal ve Kubilay tarafından yapılan çalışmada ölçeğin Cronbach Alfa güvenirlilik kat sayısı 0.90 'dır (Örsal ve Kubilay, 2007). Bu çalışma da Cronbach Alfa değeri 0.80 bulunmuştur.

\section{Verilerin Toplanması}

Veriler, araştırmaya katılmayı kabul eden kadınlarla araştırmacılar tarafından yüz yüze görüssme yöntemiyle toplandı. Verilerin toplanması her bir kadın için yaklașık 10-15 dakika sürdü.

\section{Verilerin Değerlendirilmesi}

Verilerin kodlanması ve değerlendirilmesi SPSS 25.0 paket programı kullanılarak bilgisayar ortamında gerçekleştirildi. Verilerin analizinde tanımlayıc istatistikler, bağımsız örneklem $t$ testi ve tek yönlü varyans analizi kullanıldı. Sonuçlar \% 95'lik güven aralığında, anlamlılık $\mathrm{p}<0.05$ düzeyinde değerlendi.

\section{Bulgular}

Tablo 1'de kadınların sosyo-demografik özelliklerine göre dağılımı verilmiștir. Kadınların yas ortalamasının $33.3 \pm 7.6$ olduğu, \%26.3'ünün ilkokul mezunu olduğu, \%70.3'ünün çalışmadığ 1 ve \%83.3'ünün çekirdek ailede yaşadığı belirlendi. Kadınların eşlerine ait bilgiler incelendiğinde \%28.8'inin lise mezunu olduğu saptandı (Tablo 1).

Tablo 1. Kadınların sosyo-demografik özelliklerine göre dağ 11 เmı $(\mathrm{n}=323)$

\begin{tabular}{lrr}
\hline Sosyo-Demografik Özellikler & \multicolumn{2}{c}{ Ort \pm SS } \\
\hline Yaş & n & \% \\
\hline Kadınların eğitim düzeyi & & \\
\hline Okuma-yazma bilmeyen & 41 & 12.7 \\
İlkokul mezunu & 85 & 26.3 \\
Ortaokul mezunu & 69 & 21.4 \\
Lise mezunu & 67 & 20.7 \\
Üniversite mezunu ve üzeri & 61 & 18.9 \\
\hline Eşin Ĕ̆itim Düzeyi & & \\
\hline Okuma-yazma bilmeyen & 10 & 3.1 \\
İlkokul mezunu & 76 & 23.5 \\
Ortaokul mezunu & 63 & 19.5 \\
Lise mezunu & 93 & 28.8 \\
Üniversite mezunu ve üzeri & 81 & 25.1 \\
\hline Çalışma durumu & & \\
\hline Çalışıor & 96 & 29.7 \\
Çalışmıyor & 227 & 70.3 \\
\hline Aile tipi & & 103.3 \\
\hline Çekirdek aile & 269 & 16.7 \\
\hline Geniş aile & 54 & \\
\hline Toplam & 323 & \\
\hline
\end{tabular}


Tablo 2'de kadınların obstetrik ve aile planlamasına ilişkin özelliklerine göre dağılımı verildi. Kadınların ilk gebelik yaşı ortalamasının $22.9 \pm 4.1$ olduğu ve $\% 88.5$ 'inin multigravida olduğu bulundu. Ayrıca yaşayan çocuk sayısı ortalaması $2.4 \pm 1.2$ saptandı. Kadınların \%21.7'sinin spontan düşük yaşadığı, \%6.5'inin isteyerek düşük yaptığ ve \%16.4'ünün istenmeyen gebelik yaşadığ belirlendi. Aile planlaması danışmanlığı alan kadınların oranının \%34.7 olduğu, \%56'sının herhangi bir kontrasepsiyon yöntemi kullanmadığ1, \%31.7'sinin halen gebe olduğu için herhangi bir yöntem kullanmadığı saptandı. Kadınların \%63.5'i emzirmenin gebelikten koruduğunu ve \%84.5'i ise küretajın bir aile planlaması yöntemi olarak kullanılmaması gerektiğini düşündüklerini belirtmişlerdir. Ayrıca kadınların \%36.2'si rahim içi araç kullanmanın, \%17'si kombine oral kontraseptif kullanmanın günah olduğunu düşündüklerini ifade etti (Tablo 2).

Tablo 3'de APTÖ toplamı ve alt boyutlarından alınabilecek en düşük ve en yüksek puanlar ile katılımcıların aldıkları en düşük ve en yüksek puan ve puan ortalamalarının dağılımı verilmiştir. Kadınların APTÖ'den aldıkları toplam puan ortalamasinın 109.1 \pm 18.7 , "Toplumun Aile Planlamasına İlişkin Tutumu" alt boyutundan aldıkları puan ortalamasının 48.8 \pm 10.1 , "Aile Planlamas1 Yöntemlerine İlişkin Tutum" alt boyutundan aldıkları puan ortalamasının $35.1 \pm 6.5$ ve "Doğuma İlişkin Tutum" alt boyutundan aldıkları puan ortalamasının $25.1 \pm 5.4$ olduğu saptand 1 (Tablo $3)$.

Tablo 3. Katılımciların APTÖ toplam ve alt boyutları en düşük-en yüksek puanları ve puan ortalamaları $(\mathrm{n}=323)$

\begin{tabular}{lccc}
\hline & $\begin{array}{c}\text { Alınabilecek } \\
\text { Min-Max }\end{array}$ & $\begin{array}{c}\text { Alınan } \\
\text { Min- } \\
\text { Max }\end{array}$ & Ort \pm SS \\
\hline $\begin{array}{l}\text { APTÖ Toplam } \\
\text { puanı }\end{array}$ & $34-170$ & $41-170$ & $109.1 \pm 18.7$ \\
\hline $\begin{array}{l}\text { Toplumun aile } \\
\text { planlamasına } \\
\text { yönelik tutumu }\end{array}$ & $15-75$ & $20-75$ & $48.8 \pm 10.1$ \\
\hline $\begin{array}{l}\text { Aile planlamas1 } \\
\text { yöntemlerine } \\
\text { yönelik tutum }\end{array}$ & $11-55$ & $11-55$ & $35.1 \pm 6.5$ \\
\hline $\begin{array}{l}\text { Doğuma yönelik } \\
\text { tutum }\end{array}$ & $8-40$ & $10-40$ & $25.1 \pm 5.4$ \\
\hline
\end{tabular}

Tablo 2. Kadınların obstetrik ve aile planlamasına ilişkin özelliklerine göre dağılımı

\begin{tabular}{|c|c|c|}
\hline Özellikler & \multicolumn{2}{|c|}{ Ort \pm SS } \\
\hline İlk gebelik yaşı & \multicolumn{2}{|c|}{$22.9 \pm 4.1$} \\
\hline \multirow{2}{*}{ Yaşayan çocuk sayısı } & \multicolumn{2}{|c|}{$2.4 \pm 1.2$} \\
\hline & $\mathbf{n}$ & $\%$ \\
\hline \multicolumn{3}{|l|}{ Spontan düşük } \\
\hline Evet & 70 & 21.7 \\
\hline Hayır & 253 & 78.3 \\
\hline \multicolumn{3}{|l|}{ İsteyerek düşük } \\
\hline Evet & 21 & 6.5 \\
\hline Hayır & 302 & 93.5 \\
\hline \multicolumn{3}{|l|}{ İstenmeyen gebelik } \\
\hline Evet & 53 & 16.4 \\
\hline Hayır & 270 & 83.6 \\
\hline \multicolumn{3}{|l|}{ Doğum sayısı } \\
\hline Hiç doğum yapmamış & 37 & 11.5 \\
\hline $1-2$ & 168 & 52.0 \\
\hline 3 ve üzeri & 118 & 36.5 \\
\hline \multicolumn{3}{|c|}{ Aile planlaması danışmanlığı alma } \\
\hline Evet & 112 & 34.7 \\
\hline Hayır & 211 & 65.3 \\
\hline \multicolumn{3}{|c|}{$\begin{array}{l}\text { Herhangi bir kontrasepsiyon yöntemi } \\
\text { kullanma }\end{array}$} \\
\hline Evet & 142 & 44.0 \\
\hline Hayır & 181 & 56.0 \\
\hline \multicolumn{3}{|c|}{$\begin{array}{l}\text { Aile planlaması yöntemi kullanmama } \\
\text { nedenleri* }\end{array}$} \\
\hline Halen gebe olma & 45 & 31.7 \\
\hline Çocuğum olsun istiyorum & 39 & 27.5 \\
\hline Eşim yanımda değil & 21 & 14.8 \\
\hline Eşim istemiyor & 13 & 9.2 \\
\hline Sağlığıma zararlı olduğunu & 13 & 9.2 \\
\hline düşünüyorum & & \\
\hline $\begin{array}{l}\text { Emzirdiğim için hamile } \\
\text { kalmayacağımı düșünüyorum }\end{array}$ & 11 & 7.6 \\
\hline \multicolumn{3}{|l|}{$\begin{array}{l}\text { Herhangi bir yöntemin günah } \\
\text { olduğunu düșünme }\end{array}$} \\
\hline Evet & 124 & 38.4 \\
\hline Hayır & 199 & 61.6 \\
\hline \multicolumn{3}{|l|}{ Emzirmek gebelikten korur } \\
\hline Evet & 118 & 36.5 \\
\hline Hayır & 205 & 63.5 \\
\hline \multicolumn{3}{|c|}{ Küretaj aile planlaması yöntemidir } \\
\hline Evet & 50 & 15.5 \\
\hline Hayır & 273 & 84.5 \\
\hline \multicolumn{3}{|c|}{$\begin{array}{l}\text { Spiral kullanmanın günah olduğunu } \\
\text { düşünme }\end{array}$} \\
\hline Evet & 117 & 36.2 \\
\hline Hayır & 206 & 63.8 \\
\hline \multicolumn{3}{|c|}{$\begin{array}{l}\text { Kombine oral kontraseptiflerin günah } \\
\text { olduğunu düşünme }\end{array}$} \\
\hline Evet & 55 & 17.0 \\
\hline Hayır & 268 & 83.0 \\
\hline
\end{tabular}


Tablo 4' de sosyo-demografik özelliklere göre APTÖ puan ortalamasının dağılımı verilmiştir. Kadınların ve eşlerinin eğitim düzeyi yükseldikçe APTÖ puan ortalaması yükselmektedir. Benzer şekilde, çalışan ve çekirdek ailede yaşayan kadınların APTÖ puan ortalaması farklılık göstermektedir (Tablo 4).

Tablo 5'de kadınların obstetrik ve aile planlamasına ilişkin özelliklerine göre APTÖ puan ortalamasının dağılımı verilmiştir. Spontan düşük yapanların APTÖ puan ortalaması, spontan düşüğü olmayan kadınların APTÖ puan ortalamasından yüksektir ve aralarında istatistiksel olarak anlamlı farkl11ık bulunmuştur $(\mathrm{p}<0.05) . \mathrm{Bu}$ araştırmanın sonuçlarına göre, doğum sayısı fazla olan ve aile planlaması danışmanlığı almayan kadınlarda APTÖ puan ortalamaları istatistiksel olarak farklılık göstermektedir $(\mathrm{p}<0.05)$. Ayrıca herhangi bir aile planlaması yöntemi kullanmayan ya da geleneksel yöntem kullanan kadınlarda da APTÖ puan ortalamaları anlamlı olarak farklıdır (Tablo 5).

\section{Tartıșma}

Kadınların istediği zaman, istediği sayıda ve istediği aralıklarla gebe kalmak istemesi en doğal hakkıdır. Ancak bu durum kadınların aile planlaması hakkında yeterli ve doğru bilgi sahibi olması ile mümkündür. TNSA 2018 verilerine göre, ülkemizde evli kadınların \%12'sinin karşılanmamış aile planlaması ihtiyacı olduğu saptanmıştır (TNSA, 2018). Yapılan bu araştırmada aile planlaması danışmanlığı alan kadınların oranı \%34.7 olduğu ve \%56.0'1nın herhangi bir kontrasepsiyon yöntemi kullanmadığı saptandı (Tablo 2). Benzer şekilde, Tezel ve arkadaşlarının 2015 yılında yaptıkları çalışmada, kadınların \%46.7'sı herhangi bir aile planlaması yöntemi kullanmadığını belirtmiştir (Tezel ve ark., 2015). Araştırma bulgusu çalışma ile benzerlik göstermektedir.,

Etkili bir aile planlaması yöntemi kullanmanın yararlarının kadınlara öğretilmesi, etkili olmayan yöntemlerin seçilme nedenlerinin önüne geçilmesi ve eğitimlerin yaygınlaştırılması önem verilmesi gereken konulardandır. Özellikle kırsal kesimlerde yaşayan kadınlar genellikle eş ve aile büyüklerinin izin vermemesi, günah ve infertiliteye neden olabileceğini düşündüklerinden modern aile planlaması yöntemlerini kullanmada kararsız kalmaktadırlar (Karadağ ve ark., 2013).
Tablo 4. Sosyo-demografik özelliklere göre Aile Planlaması Tutum Ölçeği puan ortalamalarının dağılımı

\begin{tabular}{|c|c|c|}
\hline $\begin{array}{l}\text { Sosyo-Demografik } \\
\text { Özellikler }\end{array}$ & Ort \pm SS & $\begin{array}{l}\text { Test ve p } \\
\text { değeri }\end{array}$ \\
\hline $\begin{array}{l}\text { Kadınların eğitim } \\
\text { düzeyi* }\end{array}$ & & \\
\hline $\begin{array}{l}\text { Okuma-yazma } \\
\text { bilmeyen }^{1}\end{array}$ & $100.2 \pm 19.0$ & $\begin{array}{r}F=19.436 \\
\mathbf{p}=\mathbf{0 . 0 0 1}\end{array}$ \\
\hline İlkokul mezunu ${ }^{2}$ & $103.1 \pm 15.3$ & $5>4,3,2,1$ \\
\hline Ortaokul mezunu ${ }^{3}$ & $107.6 \pm 14.8$ & $3>1$ \\
\hline Lise mezunu ${ }^{4}$ & $109.0 \pm 18.1$ & $1<4$ \\
\hline $\begin{array}{l}\text { Üniversite mezunu ve } \\
\text { üzeri }^{5}\end{array}$ & $125.2 \pm 18.4$ & \\
\hline
\end{tabular}

\section{Eşin eğitim düzeyi*}

\begin{tabular}{lrr}
\hline $\begin{array}{l}\text { Okuma-yazma } \\
\text { bilmeyen }\end{array}$ & $89.7 \pm 9.9^{1}$ & $\begin{array}{r}\mathrm{F}=14.104 \\
\mathbf{p = 0 . 0 0 1}\end{array}$ \\
İlkokul mezunu & $103.6 \pm 17.4$ & $5>4,3,2,1$ \\
Ortaokul mezunu & $107.4 \pm 15.6^{3}$ & $1<2,3,4,5$, \\
Lise mezunu & $107.0 \pm 17.0^{4}$ & \\
Üniversite mezunu ve & $120.5 \pm 19.7^{5}$ & \\
üzeri & & \\
\hline
\end{tabular}

\section{Çalışma durumu**}

\begin{tabular}{llr}
\hline Evet & $118.3 \pm 20.2$ & $\mathrm{t}=6.046$ \\
Hayır & $105.2 \pm 16.7$ & $\mathbf{p}=\mathbf{0 . 0 0 1}$ \\
\hline Aile tipi** & & \\
& & \\
\hline Çekirdek aile & $110.6 \pm 18.8$ & $\mathrm{t}=3.182$ \\
Geniş aile & $101.8 \pm 16.8$ & $\mathbf{p}=\mathbf{0 . 0 0 2}$ \\
\hline
\end{tabular}

*Tek Yönlü Varyans Analizi **Bağımsız gruplarda t testi

Bu araştırmada kadınların \%38.4'ü herhangi bir aile planlaması yöntemi kullanmanın günah olduğunu düşündüklerini belirtti. Kadınların \%36.2'si rahim içi araç kullanmanın, \%17'si ise kombine oral kontraseptif kullanmanın günah olduğunu düşündüklerini ifade ettiler (Tablo 2). Dönmez ve arkadaşlarının (2020) yaptıkları çalışmada, Türk kadınlarının \%32'sinin ve Suriyeli kadınların \%46'sının aile planlaması yöntemi olarak tüp ligasyonun günah olduğunu belirtmişlerdir (Dönmez ve ark., 2020). Gana (2017), Guatemala (2016) ve Pakistan'da (2019) yapilan nitel çalışmalarda, aile planlaması yöntemlerinin kürtajla eş değer ve günah olduğu belirtilmiştir (Ataullahjan ve ark., 2019; Richardson ve ark., 2016; Staveteig, 2017). 
Tablo 5. Kadınların obstetrik ve aile planlamasına ilişkin özelliklerine göre Aile Planlaması Tutum Ölçeği puan ortalamalarının dağılımı

\begin{tabular}{|c|c|c|}
\hline Özellikler & Ort \pm SS & Test ve p değeri \\
\hline \multicolumn{3}{|l|}{ Spontan düşük* } \\
\hline Evet & $105.3 \pm 16.9$ & $p=0.056$ \\
\hline Hayır & $110.2 \pm 19.1$ & \\
\hline \multicolumn{3}{|l|}{ İsteyerek düşük* } \\
\hline Evet & $105.9 \pm 14.7$ & $\mathrm{p}=0.420$ \\
\hline Hayır & $109.3 \pm 19.0$ & \\
\hline \multicolumn{3}{|l|}{ İstenmeyen gebelik* } \\
\hline Evet & $108.0 \pm 18.7$ & $\mathrm{t}=-0.458$ \\
\hline Hayır & $109.3 \pm 18.8$ & \\
\hline \multicolumn{3}{|l|}{ Doğum Sayısı*** } \\
\hline Hiç doğum yapmamış & $111.7 \pm 20.9$ & \\
\hline $1-2$ & $112.7 \pm 18.3$ & $\mathrm{~F}=9.561$ \\
\hline 3 ve üzeri & $103.2 \pm 17.3$ & \\
\hline \multicolumn{3}{|c|}{ Aile planlaması danışmanlığı alma* } \\
\hline Evet & $112.5 \pm 18.7$ & $\mathbf{p}=\mathbf{0 . 0 1 7}$ \\
\hline Hayır & $107.3 \pm 18.5$ & \\
\hline \multicolumn{3}{|c|}{ Herhangi bir kontrasepsiyon yöntemi kullanma durumu*** } \\
\hline Kullanmayan $^{1}$ & $107.6 \pm 17.1$ & $\mathrm{~F}=6.862$ \\
\hline Modern yöntem kullanan ${ }^{2}$ & $114.1 \pm 24.4$ & $2>1$ \\
\hline Geleneksel yöntem kullanan ${ }^{3}$ & $102.5 \pm 15.3$ & $2>3$ \\
\hline \multicolumn{3}{|c|}{ Herhangi bir yöntemin günah olduğunu düşünme* } \\
\hline Evet & $105.5 \pm 15.1$ & $\mathrm{t}=-2.777$ \\
\hline Hayır & $111.4 \pm 20.4$ & \\
\hline \multicolumn{3}{|c|}{ Kürtajı aile planlaması olarak düşünme } \\
\hline Evet & $108.1 \pm 21.2$ & $\mathrm{t}=-0.432$ \\
\hline Hayır & $109.3 \pm 18.3$ & \\
\hline
\end{tabular}

Literatürde doğurganlık ve aile planlaması yöntemlerinin kullanımı din, eğitim düzeyi ve toplumsal uygulamalarla ilgili olduğu düşünülmektedir (Çubukçu, 2018; Erlenwein ve ark., 2015, Gavas ve İnal, 2019; Öztaş ve ark., 2015; Selim ve Bilgin, 2020). Araştırma bulgusu literatür ile uyumludur.

İstenmeyen gebelikleri temsil eden küretajlar aile planlamas1 hizmetlerinin değerlendirilmesinde önemli bir göstergedir (Oltuluoğlu ve Başer, 2012). Yapılan bu araştırmada kadınların \%84.5'i küretajın bir aile planlaması yöntemi olmadığını düşündüklerini belirttiler. Benzer şekilde, Çakmak ve arkadaşları çalışmalarında, kadınların \%90'ının küretajın bir aile planlaması yöntemi olmadığını düşündüklerini bildirmişlerdir. (Çakmak ve ark., 2015). Oltuluoğlu ve Başer (2012)'in yaptıkları çalışmada, kadınların \%36.6'sının istenmeyen gebelik yaşadığını ve istenmeyen bu gebeliklerin \%40.3'ünün düşük ya da kürtajla sonuçlandığını saptamışlardır (Oltuluoğlu ve Başer, 2012). FontRibera ve arkadaşları (2008) yaptıkları çalışmada, katılımcıların \%41'inin istenmeyen gebeliğe sahip olduğunu ve bu gebeliklerin \%60'inın kürtajla sonuçlandığını saptanmışlardır (Font-Ribera ve ark., 2008). Budak ve arkadaşları 2015 yılında yaptıkları çalışmada ise, küretaj ile sonuçlanan gebeliklerin \% 94'ünün plansız olduğunu belirtmişlerdir (Budak ve ark., 2015). Araştırma bulgusu literatür ile uyumludur. 
Laktasyonel amenore yöntemi, emzirme ile fertilizasyonun baskılanması sonucu oluşmaktadır. Postpartum dönemdeki anneler tarafindan kontraseptif yöntem olarak tercih edilmesine rağmen tam emzirme olmadıkça gebelikten koruyucu etkisinin düşük olduğu belirtilmektedir (Egelioğlu Cetişli ve ark., 2020). Araştırmada kadınların \%63.5'i emzirmenin gebelikten koruduğunu belirtmişlerdir. Yapılan bir çalışmada kadınların \%52.5'i emzirmenin gebelikten yüzde yüz koruyucu olduğunu ve emziren annenin gebe kalmayacağını ifade etmiștir (Elkin, 2015). Karabulutlu ve Ersöz'ün (2017) yaptıkları çalışmada, kadınların \%44.4'ü emzirmenin gebelikten koruduğunu belirtmişlerdir (Karabulutlu ve Ersöz, 2017). Çalışma sonuçları araştırma bulgusunu destekler niteliktedir.

Araştırmada APTÖ'nin toplamından ve alt boyutlarından alınabilecek en düşük ve en yüksek puanlar doğrultusunda kadınların puan ortalamaları incelendiğinde; kadınların aile planlamasına yönelik genel tutumlarının $(109.1 \pm 18.7)$, toplumun aile planlamasına ilişkin tutumlarının $(48.8 \pm 10.1)$, aile planlaması yöntemlerine ilişkin tutumlarının (35.1 \pm $6.5)$ ve doğuma ilişkin tutumlarının $(25.1 \pm 5.4)$ orta düzeyde olduğu söylenebilir (Tablo 3). Ejder Apay ve arkadaşlarının (2010) Erzurum'da yaptıkları çalışmada 36 ve üzeri yaş grubunda olan kadınların APTÖ puan ortalaması $(109.04 \pm 19.82), 18$-35 yaş grubuna (116.25 \pm 17.93$)$ göre daha düşük bulunmuştur. Ayrica kadınların toplumun aile planlamasına ilişkin tutumlarının $(51.88 \pm 0.52)$, aile planlaması yöntemlerine ilişkin tutumlarının $(36.72 \pm 0.29)$ ve doğuma ilişkin tutumlarının (28.73 \pm 0.26$)$ orta düzeyde olduğu saptanmıştır (Ejder Apay ve ark., 2010). Ayaz ve Yaman Efe'nin 2009 yılında yaptıkları çalışmada, kadınların aile planlamasına yönelik genel tutumlarının (120.1 \pm 13.8$)$, toplumun aile planlamasına ilişkin tutumlarının $\quad(54.80 \pm 8.1), \quad$ aile planlamas1 yöntemlerine ilişkin tutumlarının $(36.81 \pm 5.2)$ ve doğuma ilişkin tutumlarının (28.50 \pm 4.2$)$ iyi düzeyde olduğu saptanmıştır (Ayaz ve Yaman Efe, 2009). Gözükara ve arkadaşlarının 2015 yılında yaptıkları çalışmada, kadınların aile planlamasına yönelik genel tutumlarının (124.20 \pm 27.34$)$, toplumun aile planlamasına ilişkin tutumlarının $(54.75 \pm 14.10)$, aile planlaması yöntemlerine ilişkin tutumlarının $(38.87 \pm 8.20)$ ve doğuma ilişkin tutumlarının (29.70 \pm 5.96$)$ iyi düzeyde olduğu belirtilmiştir (Gözükara ve ark., 2015). Tezel ve arkadaşlarının (2015) çalışmasında ise, kadınların aile planlamasına yönelik genel tutumlarının
(130.72 \pm 26.10$)$, toplumun aile planlamasına ilişkin tutumlarının $(59.13 \pm 12.25)$, aile planlamas yöntemlerine ilişkin tutumlarının $(41.41 \pm 9.46)$ ve doğuma ilişkin tutumlarının $(30.18 \pm 7.24)$ iyi düzeyde olduğu söylenebilir (Tezel ve ark., 2015). Alan Dikmen ve arkadaşlarının (2019) Türkiye'deki Suriyeli mülteci kadınlar ile yaptıkları çalışmada, kadınların aile planlamasına yönelik tutumlarının $(94.67 \pm 17.48)$ orta düzeyde olduğu saptanmıştır (Alan Dikmen ve ark., 2019). Aydın Avc1 ve arkadaşlarının (2018) Türkiye'nin kuzeyinde yaşayan Roman kadınlar ile yaptıkları çalışmada, kadınların aile planlamasına yönelik genel tutumlarının $(74.9 \pm 9.64)$, toplumun aile planlamasına ilişkin tutumlarının $(27.8 \pm 5.08)$, aile planlaması yöntemlerine ilişkin tutumlarının (26.8 \pm 6.69) ve doğuma ilişkin tutumlarının $(20.1 \pm 2.13)$ düşük düzeyde olduğu saptanıştır (Aydın Avcı ve ark., 2018). Kashmir'de sağlık çalışanları ile yapılan çalışmada, katılımcıların yaklaşık \%80.1'inin aile planlamasına karşı olumlu bir tutuma sahip olduğu bulunmuştur (Wani ve ark., 2019). Kuzeybat1 Etiyopya'da 2018 yılında yapılan bir çalışmada ise, aile planlamasına yönelik bilgi ve tutum düzeyinin düşük olduğu belirtilmiştir (Semachew Kasa ve ark., 2018). Çalışmalardaki farkın yerleşim yerlerindeki farklılıktan kaynaklandığ 1 düşünülmektedir. Aile planlamas1 tutumunun iyi düzeyde olmamasının, ilgili bölgede yaşayan kadınların aile planlaması yöntemlerine yönelik bilgi düzeylerinin düşük olmasından ve ataerkil yapının egemen olduğu toplumsal bir yapının etkin olmasından kaynaklandığı düşünülebilir.

Araştırmada kadınların ve eşlerinin eğitim düzeyi ile APTÖ puan ortalamaları arasındaki farkın istatistiksel olarak anlamlı olduğu bulundu (Tablo 4). Literatür incelendiğinde, yapılan çalışmalarda kadınların eğitim düzeyi yükseldikçe aile planlamasına yönelik olumlu tutumların da anlamlı derecede arttığı görülmektedir. (Ayaz ve Yaman Efe, 2009; Çıtak Bilgin ve Tokur Kesgin, 2020; Ejder Apay ve ark., 2010; Gözükara ve ark., 2015; Gür ve Sohbet, 2017; Tezel ve ark., 2015). Nikolic ve Djikanovic (2015), eğitim düzeyi ile aile planlaması yönteminin kullanımı arasında pozitif bir ilişki olduğunu belirtmişlerdir (Nikolic ve Djikanovic, 2015).

Araştırmada çalışan kadınlar ve çekirdek ailede yaşayan kadınların APTÖ puan ortalaması anlamlı olarak yüksek olduğu saptandı (Tablo 4). Yapılan çalışmalarda çalışan kadınların APTÖ puan ortalamasının çalışmayan kadınlara göre daha yüksek olduğu saptanmıştır (Ejder Apay ve ark., 
2010; Eryılmaz ve Ege, 2016; Tezel ve ark., 2015). Diğer yandan Alan Dikmen ve arkadaşlarının (2019) yaptıkları çalışmada, kadınların çalışma durumunun APTÖ puan ortalamasını etkilemediği saptanmıştır (Alan Dikmen ve ark., 2019). Genet ve arkadaşlarının 2015 yılında yaptıkları çalışmada, ev hanımı/çiftçi olan kadınların karşılanmamış kontrasepsiyon ihtiyaçlarının, çalışan kadınlara göre yaklaşık yedi kat daha fazla olduğu bulunmuştur (Genet ve ark., 2015). Çalışan kadınların aile planlamasına yönelik tutumlarının olumlu olmasının nedeni, ekonomik bağımsızlıkları nedeniyle aile planlaması hizmetlerine ulaşımlarının daha kolay olması ve istedikleri yöntemi temin edebilme olasılıklarının daha fazla olmasına bağlı olduğu düşünülmektedir. Yapılan çalışmalarda, yaşanılan aile tipine göre APTÖ puan ortalaması karşılaştırıldığında; çekirdek ailede yaşayanların puanları geniş ailede yaşayanlara oranla daha yüksek olduğu bulunmuştur (Ejder Apay ve ark., 2010; Eryılmaz ve Ege, 2016; Gözükara ve ark., 2015). Diğer yandan, bazı çalışmalarda kadınların yaşadıkları aile yapılarının APTÖ puan ortalamasını etkilemediği saptanmıştır (Alan Dikmen ve ark., 2019; Ayaz ve Yaman Efe, 2009; Tezel ve ark., 2015). Bölge kültüründe, diğer kararlarda olduğu gibi, aile büyüklerinin, özellikle de kayınvalidenin etkisinin, aile planlamasında geniş aile kadınlarının bağımsız karar alma ve tutumlarını etkileyeceğine inanılmaktadır.

Araştırmada kendiliğinden düşük yapanların APTÖ puan ortalamasının düşük olduğu görülmüştür ve aralarındaki ilişki anlamlıdır (Tablo 5). Gözükara ve arkadaşlarının (2015) yaptıkları çalışmada daha önce düşük yapan kadınların aile planlaması tutumlarının daha olumsuz olduğu, Ejder Apay ve arkadaşlarının (2010) yaptıkları çalışmada düşük yapmış kadınların aile planlaması tutumlarının anlamlı derecede daha olumsuz olduğu ve düşük sayısı arttıkça olumsuz tutumların da arttığ1 belirtilmiştir (Ejder Apay ve ark., 2010; Gözükara ve ark., 2015). Tezel ve arkadaşlarının (2015) yaptıkları çalışmada ise kadınların düşük sayısı ile APTÖ puan ortalamaları arasında istatistiksel olarak anlamlı bir fark olmadığ belirlenmiştir (Tezel ve ark., 2015)

Araştırmada doğum sayısı fazla olan ve aile planlaması konusunda danışmanlık almayan kadınlarda APTÖ puan ortalamasının düşük olduğu saptand1 (Tablo 5). Literatür incelendiğinde, kadınların yaşayan çocuk sayısı arttıç̧a, APTÖ puan ortalamasının düştüğü ve aralarındaki farkın istatistiksel olarak anlamlı olduğu belirlenmiştir
(Egelioğlu Cetişli ve ark., 2020; Ejder Apay ve ark., 2010; Gözükara ve ark., 2015; Tezel ve ark., 2015). Alan Dikmen ve arkadaşlarının (2019) çalışmasında kadınların istedikleri sayıda çocuk sahibi olmaları ve yaşayan çocuk sayısı ile APTÖ puanı arasında istatistiksel olarak anlamlı ilişki olduğu saptanmıştır (Alan Dikmen ve ark., 2019). Aile planlamas1 yöntemlerinin yalnızca doğum kontrol yöntemi olarak görüldüğü ve çok sayıda çocuğa sahip olmanın daha yüksek bir sosyal statü olarak görüldügüu ülkelerde, çok sayıda çocuğa sahip olmayı istemenin aile planlaması üzerinde olumsuz etkileri vardır. Aile planlaması konusunda danışmanlık almanın kadınların doğru bilgi ve uygulamalarını artırdığı bilinmektedir. Yapılan bir çalışmada aile planlaması yöntemlerinin kullanımını gerekli bulan, yöntemler hakkında bilgi alan ve bu konuda bilgi almaya istekli olan kadınların, yöntem kullanımını gereksiz bulan, bu konuda daha önce bilgi almayan ve bilgi almayı gereksiz bulan kadınlara göre aile planlaması tutumlarının daha olumlu olduğu saptanmıştır (Çıtak Bilgin ve Tokur Kesgin, 2020). Eryılmaz ve Ege'nin (2016) yaptıkları çalışmada, aile planlaması danışmanlık hizmeti alan kadınlarda, APTÖ puan ortalamasının daha yüksek ve aralarındaki farkın istatistiksel olarak anlamlı olduğu bulunmuştur (Eryılmaz ve Ege, 2016). Ayrıca yapılan çalışmalarda, yanlış bilgi ve mitlerin aile planlamas1 tutumunu olumsuz etkilediği bildirilmektedir (Ankomah ve ark.,2011; Sultan ve ark., 2018). Kadınların aile planlaması danışmanlığı alma durumlarının, aile planlamasına ilişkin tutumlarını olumlu yönde etkilediği düşünülebilir.

Aile planlaması yöntemi kullanmama oranı, diğer bölgelere göre Kuzey Doğu Anadolu'da (\%36.5) en yüksek orandadır (TNSA, 2018). Araştırmada herhangi bir aile planlaması yöntemi kullanmayan ya da geleneksel yöntem kullanan kadınlarda da APTÖ puanının düşük olduğu bulunmuştur (Tablo 5). Literatürde, herhangi bir aile planlaması yöntemi ve modern yöntem kullanan kadınların, yöntem kullanmayan ve geleneksel yöntemleri kullanan kadınlara göre daha yüksek APTÖ puan ortalamasına sahip olduğu görülmektedir (Ayaz ve Yaman Efe, 2009; Ejder Apay ve ark., 2010). Tezel ve arkadaşlarının (2015) yaptıkları çalışmada ise, aile planlaması yöntemi kullananların APTÖ puan ortalamasının (131.51 \pm 26.00$)$ kullanmayanların APTÖ puan ortalamasına göre $(129.82 \pm 26.23)$ daha yüksek olduğu, ayrıca geleneksel yöntem kullananların 
APTÖ puan ortalamasının (132.81 \pm 27.68$)$ modern yöntem kullananların APTÖ puan ortalamasından (131.39 \pm 25.85$)$ daha yüksek olduğu saptanmıştır ve bu farklar istatistiksel açıdan anlamlı bulunmamıştır (Tezel ve ark., 2015). Benzer şekilde Gözükara ve arkadaşlarının (2015) yaptıkları çalışmada, kadınların aile planlaması yöntemi kullanma özelliklerine göre APTÖ puan ortalaması incelendiğinde; aile planlaması yöntemi ve modern yöntem kullanma durumu ile APTÖ puan ortalaması arasında istatistiksel açıdan anlamlı fark olmadığı bulunmuştur (Gözükara ve ark., 2015). Chopra ve Dhaliwal (2010) tarafindan yapılan bir çalışmada da araştırmaya katılan kadınların uzun süreli aile planlaması kullanım oranlarının düşük olmasına rağmen aile planlamasına karşı tutumlarının olumlu olduğu belirtilmiştir (Chopra ve Dhaliwal, 2010). Etkin aile planlaması yöntemi kullanımının, aile planlamasına karşı olumlu bir tutum geliştirilmesinde etkili olduğu düşünülmektedir. $\mathrm{Bu}$ araștırmada kadınların çoğunluğu kürtajın bir aile planlaması yöntemi olmadığını belirtmiştir (Tablo 5). Gözükara ve arkadaşlarının yaptıkları çalışmada, kürtaj sayısı ile APTÖ puan ortalaması arasında istatistiksel açıdan anlamlı fark bulunmamıştır (Gözükara ve ark., 2015). Bu sonuç kadınların, dini inançları ve kürtajın üreme sağlı̆̆ üzerine olumsuz etkileri ile ilişkili olabilir.

\section{Sonuç ve Öneriler}

Aile planlaması hizmetlerini yürüten en önemli sağllk profesyonelleri ebeler ve hemşirelerdir. Kadınların aile planlamasına ve doğurganlığa ilişkin tutumlarının, kullandıkları kontraseptif yöntemlerin belirlenmesi planlanacak ebelik ve hemşirelik girişimlerine rehberlik edebilecektir. Bu araştırmada kadınların \%38.3'ü herhangi bir aile planlaması yöntemi kullanmanın günah olduğunu ifade etti, $\% 63,5$ 'i ise emzirmenin gebelikten koruduğunu belirtmiştir. Araştırmanın sonucunda, kadınların aile planlaması yöntemlerine ilişkin tutumlarının pozitif olduğu ancak aile planlaması yöntemi kullanma durumunun istendik düzeyde olmadığı belirlendi. Kadınların ve eşlerinin eğitim düzeyi yükseldikçe APTÖ puan ortalamaları yükselmektedir. Ayrıca çalışan kadınlarda ve çekirdek ailede yaşayan kadınların APTÖ puan ortalamaları anlamlı olarak yüksektir. Çocuk sayısı fazla olan, aile planlaması konusunda danışmanlık almayan ve herhangi bir aile planlaması yöntemi kullanmayan ya da geleneksel yöntem kullanan kadınlarda da APTÖ puanının düşük olduğu bulundu. Bu sonuçlar doğrultusunda; sorunun çözümü için kadınların statüsünün iyileştirilmesine öncelik verilmesi, eğitim olanaklarının arttırılması önemlidir. Aile planlamasına yönelik tutumların belirlenmesi ve varsa yanlış tutumların düzeltilmesi için kadınlara eğitim imkânının sağlanması, aile planlamasına yönelik eğitim ve danışmanlık hizmetlerinin verilmesi, kadınların bu hizmetlere ulaşmasında eşitlik ve hakkaniyetin sağlanması, modern aile planlaması yöntemlerinin kullanımının yaygınlaştırılması önerilebilir.

\section{Araştırmanın Sınırlılıkları}

$\mathrm{Bu}$ araştırmanın bazı sınırlılıkları vardır. Çalışmanın ilk sınırlılığı sadece şehir merkezinde ve aile hekimliklerinde yapılmış olmasıdır. İkinci sinırlılık, sözlü iletişim kurabilen ve araştırmaya katılmaya gönüllü olan kadınların dahil edilmesidir. Diğer kısıtlılıklar ise çalışmanın veri toplama formlarındaki sorulara verilen yanıtların kadın ifadelerine dayalı olmasidır.

Araştırmanın Etik Yönü/ Ethics Committee Approval: Araştırmanın yürütülebilmesi için, Bingöl Üniversitesi Bilimsel Araştırma ve Yayın Etik Kurulundan etik izin (Karar No: 92342550/044) alınmıştır. Çalışmanın amacı katılımcılara ayrıntılı olarak açıklanmış, katılımın gönüllülük esasına dayalı olduğu, gizlilik ve mahremiyet haklarının saklı tutulacağı ve istedikleri zaman çalışmadan çekilebilecekleri hakkında bilgilendirilerek, görüşmelerin yapılması ve kaydedilmesi için katılımcılardan bilgilendirilmiş onam alınmıştır. Araştırmada Helsinki Deklarasyonu ilkelerine uyulmuştur.

Hakem/Peer-review: D1ş hakem değerlendirmesi.

Yazar Katkısi/Author Contributions: Fikir/kavram: FN, ŞM.MS; Tasarım: FN, ŞM, MS; Danışmanlık: FN, ŞM, ÖDY; Veri toplama: FN, ŞM; Veri işleme: FN, ŞM; Analiz ve/veya Yorum: FN, ŞM, ANY, ÖDY; Kaynak tarama: FN, ANY, ÖDY; Makalenin Yazımı: FN, ANY, ÖDY; Eleştirel inceleme: FN, ŞM, ANY, ÖDY, MS. Tüm yazarlar eşit katkıda bulunmuştur.

Çıkar çatışması/Conflict of interest: Araştırmacılar herhangi bir çıkar çatışması belirtmemişlerdir.

Finansal Destek/Financial Disclosure: $\mathrm{Bu}$ araştırma için finansal destek alınmamıştır.

\section{Çalışma Literatüre Ne Kattı?}

- Araştırmanın sonuçlarına göre kadınların aile planlaması yöntemlerine yönelik tutumları pozitif olmasına rağmen istenilen düzeyde değildir.

- Kadınların pozitif olan tutumlarına rağmen istenilen düzeyde aile planlaması danışmanlıği ve desteği almalarının önündeki engellerin belirlenmesinin önemi bu araştırmayla ortaya konmuştur. Yeterli düzeyde hizmet alamayan risk gruplarının 
belirlenmesi, hizmet alımının önündeki engellerin tanımlanması ve çözümüne yönelik planlamaların yapılması önemli bir durumdur.

- Kadının çalışma durumu, çekirdek aile yapısında olması, aile planlaması konusunda danışmanlık alması, kendisinin ve eşinin eğitim düzeyinin yüksek olması aile planlaması tutumlarını olumlu etkilemektedir. $\mathrm{Bu}$ sonuca göre çalışmayan, geniş ailede yaşayan, aile planlaması konusunda danışmanlık almamış/alamamış, eğitim düzeyi düşük olan kadınların karşılanmamış kontrasepsiyon ihtiyaçlarının olabileceği ortaya çıkmıştır.

- Bu sonuçlar, aile planlaması hizmetlerini planlamada ebe ve hemşirelere yol gösterici olacak ve karşılanmamış kontrasepsiyon ihtiyacının azalmasını sağlayacaktır.

\section{Kaynaklar}

Alan Dikmen H, Cankaya S, Dereli Yilmaz S. (2019). The attitudes of refugee women in Turkey towards family planning. Public Health Nursing (Boston, Mass.), 36(1), 45-52.

Ankomah A, Anyanti J, Oladosu M. (2011). Myths, misinformation, and communication about family planning and contraceptive use in Nigeria. Open Access Journal of Contraception, 2, 95-105.

Ataullahjan A, Mumtaz Z, Vallianatos H. (2019). Family planning, Islam and sin: Understandings of moral actions in Khyber Pakhtunkhwa, Pakistan. Social Science \& Medicine (1982), 230, 49-56.

Arslan S, Okcu G, Coşkun AM, Temiz F. (2019). Kadınların gebeliği algılama durumu ve bunu etkileyen faktörler. Sağlık Bilimleri ve Meslekleri Dergisi, 6(1), 179-192.

Ayaz S, Yaman Efe S. (2009). Family planning attitudes of women and affecting factors. Journal of The Turkish German Gynecological Association, 10(3), 137-141.

Aydın Avcı I, Cavusoglu F, Aydın M, Altay B. (2018). Attitude and practice of family planning methods among Roma women living in northern Turkey. International Journal of Nursing Sciences, 5(1), 3338.

Bostancı M. (2011). Doğu Anadolu bölgesindeki bir ilçede kadınların kullandıkları kontraseptif yöntemleri için bilgi kaynakları ve istenmeyen gebeliklerle ilişkisi. Dicle Tıp Dergisi, 38 (2), 202 207.

Budak M, Toğrul C, Balsak D, Sakar M, Tahaoğlu A, Akgöl S ve ark. (2015). İsteğe bağl1 küretaj olan kadınların kontrasepsiyon yöntemleri ve küretaj nedenleri açısından değerlendirilmesi. JinekolojiObstetrik ve Neonatoloji Tıp Dergisi, 12(3), 106-109.

Chopra S, Dhaliwal L. (2010). Knowledge, attitude and practices of contraception in urban population of North India. Archives of Gynecology and Obstetrics, 281(2), 273-277.
Çakmak B, Metin FZ, Özsoy AZ, Çıtıl R, Önder Y, Y1lmaz Doğru H. (2014). Opinion of women about elective abortion. Turkish Journal of Obstetrics and Gynecology, 11(3), 170-175.

Çıtak Bilgin N, Tokur Kesgin M. (2020). Kanath sektöründe çalışan kadınların aile planlaması ve acil kontrasepsiyona ilişkin bilgi ve tutumlarının belirlenmesi. Sağlık Bilimleri Dergisi, 29(2), 123132.

Çubukçu M. (2018). Samsun ili 15-49 yaş grubu kadınların aile planlaması yöntemlerini kullanım dağılımı. Ankara Medical Journal, 18(2), 207-214.

Dönmez S, Gümüşsoy S, Koçak SH. (2020). Views of Turkish and Syrian refugee women who are from two different cultures on tubal ligation. Ankara Medical Journal, (2), 298-314.

Egelioğlu Cetişli N, Kahveci M, Işık S, Hacılar A. (2020). Kadınların postpartum kontraseptif tercihleri ve tutumlar1. Journal of Academic Research in Nursing, 6(1), 67-72.

Ejder Apay S, Nazik E, Özdemir F, Pasinlioğlu T. (2010). Kadınların aile planlamasına ilişkin tutumlarının belirlenmesi. Anadolu Hemşirelik ve Sağlık Bilimleri Dergisi, 13(3), 1-7.

Elkin N, Ören MM, Demirel A, Önal AE. (2015). Bir aile sağliği merkezine başvuran gebelerin anne sütü ve emzirmeye ilişkin bilgi ve tutumları. Sürekli Tıp Eğitimi Dergisi, 24(2), 41-48.

Erlenwein J, Kundu S, Schippert C, Soergel P, Hillemanns P, Staboulidou I. (2015). Attitude toward, acceptance of and knowledge about female sterilization as a method of contraception. European Journal of Obstetrics, Gynecology, and Reproductive Biology, 185, 83-87.

Eryılmaz N, Ege E. (2016). Doğum sonu dönemdeki kadınların aile planlaması konusundaki tutumları ve ilişkili faktörler. Journal of Human Sciences, 13(2), 3389-3401.

Font-Ribera L, Pérez G, Salvador J, Borrell C. (2008). Socioeconomic inequalities in unintended pregnancy and abortion decision. Journal of Urban Health: Bulletin of The New York Academy of Medicine, 85(1), 125-135.

Gavas E, İnal S. (2019). Türkiye'de kadınların aile planlaması yöntemleri kullanma durumları ve tutumları: Sistematik derleme. Sağlık ve Yaşam Bilimleri Dergisi, 1(2), 37-43.

Genet E, Abeje G, Ejigu T. (2015). Determinants of unmet need for family planning among currently married women in Dangila town administration, Awi Zone, Amhara regional state; a cross sectional study. Reproductive health, 12, 42.

Gözükara F, Kabalcığlu F, Ersin F. (2015). Şanlıurfa ilinde kadınların aile planlamasına ilişkin tutumlarının belirlenmesi. Harran Üniversitesi Tip Fakültesi Dergisi, 12(1), 9-15. 
Gür F, Sohbet R. (2017). Gaziantep ilinde el beceri kurslarına gelen kadınların aile planlamasına yönelik, bilgi tutum ve davranışları. Medical Sciences, 12(1), 10-21.

Karabulutlu Ö, Ersöz B. (2017). Kars ili, Susuz ilçe merkezine bağlı aile planlaması yöntemi kullanan 1549 yaş grubu evli kadınlarda kullanılan yöntem ve yöntem seçimini etkileyen faktörler. Caucasian Journal of Science, 4 (1), 26-44.

Karadağ G, Koçak H, Yılmaz M. (2013). Kadınların gebeliği önleyici yöntemleri kullanma ve tercih etme nedenleri. Gümüşhane Üniversitesi Sağlık Bilimleri Dergisi, 2(1), 13-25.

Kul Uçtu A, Karakoç H, Özerdoğan N. (2018). Evlendirme dairesine başvuran kadınların aile planlaması yöntem kullanımı ve hizmet alımına ilişkin görüşlerinin değerlendirilmesi. İnsan ve Toplum Bilimleri Araştırmaları Dergisi, 7(1), 12-21.

Nikolic Z, Djikanovic B. (2015). Differences in the use of contraception between Roma and non-Roma women in Serbia. Journal of Public Health, 37(4), 581-589.

Oltuluoğlu H, Başer M. (2012). Malatya il merkezinde yaşayan evli kadınların kullandıkları aile planlaması yöntemleri ve seçme nedenlerinin incelenmesi. İnönü Üniversitesi Tıp Fakültesi Dergisi, 19(3), 167-174.

Öngen M, Kırca N. (2020). Mülteci ve göçmen kadınlarda kadın sağlığı sorunları. Atatürk Üniversitesi Kadın Araştırmaları Dergisi, 2(2) ,55-69.

Örsal Ö, Kubilay G. (2014). Aile planlaması tutum ölçeğinin geliştirilmesi. Florence Nightingale Journal of Nursing, 15(60), 155-164.

Öztaş Ö, Baydar Artantaş A, Kayhan Tetik B, Yalçıntaş A, Üstü Y, Uğurlu M. (2015). 18-49 yaş grubu evli kadınların üreme sağlığı ve kontrasepsiyon hakkındaki bilgi, tutum ve davranışları. Ankara Medical Journal, 15(2), 67-76.

Richardson E, Allison KR, Gesink D, Berry A. (2016). Barriers to accessing and using contraception in highland Guatemala: the development of a family planning self-efficacy scale. Open Access Journal of Contraception, 7, 77-87.

Selim S, Bilgin D. 2020. Dini inanışlara göre doğurganlığ1 etkileyen faktörlerin etkileşim hipotezi açısından araştırılması. Afyon Kocatepe Üniversitesi Sosyal Bilimler Dergisi, 22(4), 1005-1019.

Semachew Kasa A, Tarekegn M, Embiale N. (2018). Knowledge, attitude and practice towards family planning among reproductive age women in a resource limited settings of Northwest Ethiopia. BMC Research Notes, 11(1), 577.

Staveteig S. (2017). Fear, opposition, ambivalence, and omission: Results from a follow-up study on unmet need for family planning in Ghana. PloS One, 12(7), e0182076.
Sultan S, Ali MM, Bardai SS, Kanpurwala MA, Punjwani FS. (2018). Knowledge, attitude, and practice of family planning methods among married men and women. Journal of Women's Health, 7(3), 1-3.

Şenoğlu A, Çoban A, Karaçam Z. (2019). İstenmeyen gebelikler ve isteyerek yapılan düşüklerin değerlendirilmesi. Archives Medical Review Journal, 28(4), 300-305.

Tezel A, Gönenç İ, Akgün Ş, Öztaş Karataş D, Altuntaş Yıldız T. (2015). Kadınların aile planlamasına yönelik tutumları ve etkileyen faktörler. Anadolu Hemşirelik ve Sağlık Bilimleri Dergisi, 18(3), 181-188.

Türkiye Nüfus Sağlık Araştırması (TNSA) 2018 Ana Raporu, Hacettepe Üniversitesi Nüfus Etütleri Enstitüsü. Erişim tarihi: 13.02.2021 http://www.hips.hacettepe.edu.tr/tnsa2018/rapor/TN SA2018_ana_Rapor.pdf

Wani RT, Rashid I, Nabi SS, Dar H. (2019). Knowledge, attitude, and practice of family planning services among healthcare workers in Kashmir- a crosssectional study. Journal of Family Medicine and Primary Care, 8(4), 1319-1325. 